\title{
電気制御システムと計装制御システムの融合
}

\author{
東芝三菱電機産業システム株式会社 (TMEIC) ${ }^{* 1}$ 産業第二システム事業部 システム技術第二部 \\ ○太田宏 ${ }^{* 2}$, 上野敬
}

\section{Integration of Electrical and Instrumentation Control Systems}

\author{
OHiroshi Ota*2 and Takashi Ueno \\ Paper \& Material Handling Systems Engineering Department Industrial Automation and \\ Drive Systems Division TOSHIBA MITSUBISHI-ELECTRIC INDUSTRIAL SYSTEMS \\ CORPORATION-TMEIC- ${ }^{* 1}$
}

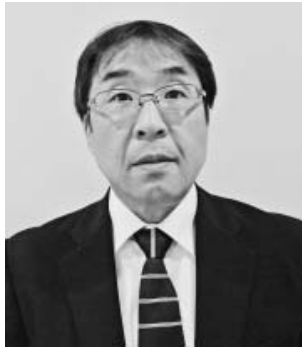

太田 宏

\begin{abstract}
Electrical and instrumentation control systems have become essential for the operation of all equipment in the field of manufacturing industry. Specification and application of electrical and instrumentation control systems are different. This paper introduces the capability of system unification utilizing unified controllers nv series.
\end{abstract}

分類： $V_{1}$ 計装・制御システム一般, $V_{2}$ 紙パルプ工程制御システム

\section{1. はじめに}

製紙工場等の生産現場において，電気制御システムと計 装制御システムはあらゆる設備の運転に必要不可欠なもの となっている。制御対象が大きく異なることから両者の仕

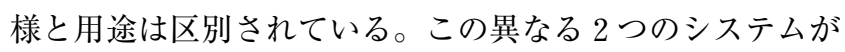
融和し, 協調できる部分の可能性と電気・計装の統一プラ ットフォームである株東芝製ユニファイドコントローラ nv シリーズの適用を本稿で紹介する。

\section{2. 製造工場における電気・計装融合システムの コンセプト}

一般産業分野では, 電気担当と計装担当の部門統合が近 年推進されている。東芝三菱電機産業システム(株)（略称 TMEIC）は，(株東芝と三菱電機株)の製造業プラント向け 電気設備事業を統合し，製造業プラント向けを主体とした 産業システムのエンジニアリング・製造・販売会社として 2003 年 10 月に設立された。紙パルプ, 石油・化学, 鉄鋼 を初めとするプラント向け産業システムの電気・計装監

\footnotetext{
${ }^{* 1} \mathbf{T} 108-0073$ 東京都港区三田 3-13-16/3-13-16 Mita,

Minato-ku, Tokyo 108-0073, Japan

${ }^{* 2} \mathrm{E}-$ mail : OHTA.hiroshi@tmeic.co.jp
}

視・制御，エンジニアリングを業務の範疇としている。電 気・計装監視・制御，エンジニアリングの営業・技術・設 計・品質管理が業種毎に組織構成されているため, 電気・ 計装担当が同じ所属で活動しており，紙パルプ分野も同様 である。このように当社では，分野別に電気・計装・計算 機技術者が集結しており, 融合システムの検討・提案に適 した環境が整備されている。

さて, 製造工場で追求される課題として, 従来から下記 が挙げられている。

(1)環境を考慮した省力・省エネ・省コスト

(2) 保守性向上

(3) 信頼性 · 品質向上

(4) 長寿命化

(5) 在庫削減

上記の課題解決のために, 電気・計装及び計算機を含め た融合システムが目標とするコンセプトとして以下が必要 とされる。図 1 に課題と要因解析及びコンセプトを示す。

(1) 情報の融合

(2) プラットフォームの融合

(3) エンジニアリングの融合

(4) 業務の融合

紙パルプ製造設備において各コンセプトを実現するため の電気・計装システム融合について紹介する。3 章では情 


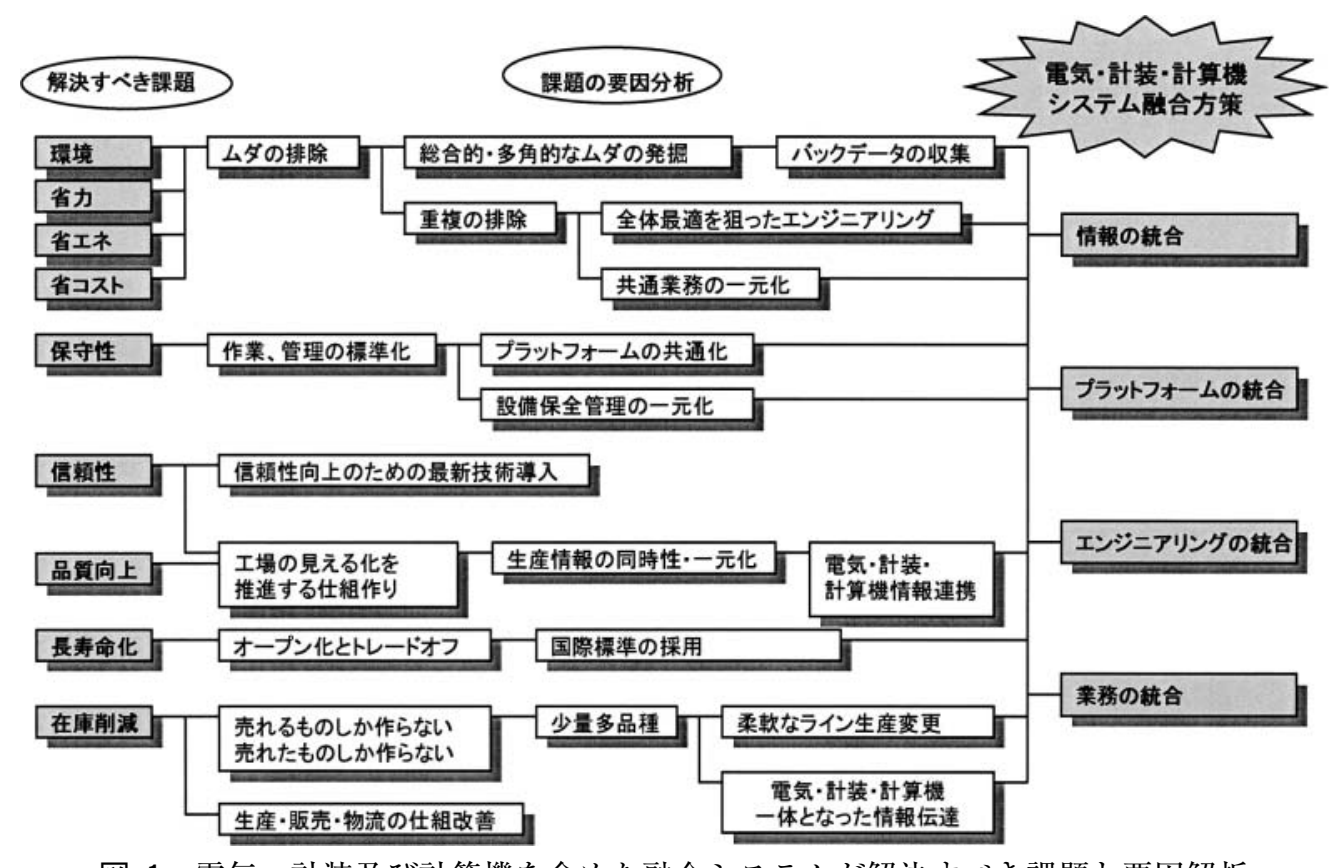

図 1 電気・計装及び計算機を含めた融合システムが解決すべき課題と要因解析

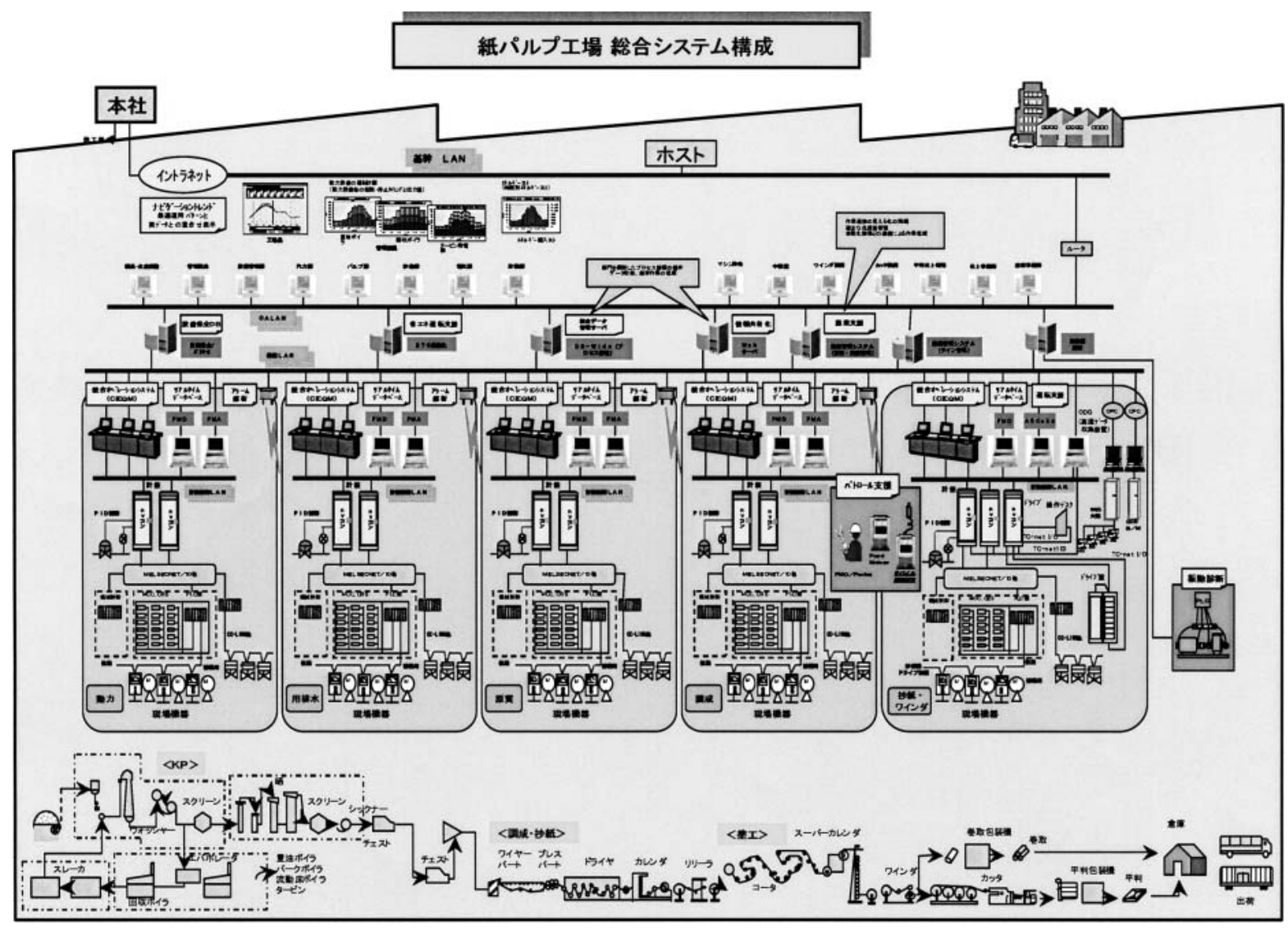

図 2 製紙工場の総合システム構成

報の融合，4 章では電気制御システム用監視装置と DCS オペレータステーション・リアルタイムデータベースの融 合， 5 章では電気・計装エンジニアリングの融合について 述べる。
3. 抄紙機電気制御システムと抄紙・調成計装 制御システムの情報融合

製紙工場には，動力，原質・パルプ製造，抄紙・調成， 
表 1 ユニファイドコントローラ nv シリーズ 電気制御用と計装制御用

\begin{tabular}{|c|c|c|}
\hline & 電気制御用 & 計装制御用 \\
\hline プログラム容量 & $256 \mathrm{~K}$ ステップ & 512 K ステップ \\
\hline ローカル変数/グローバル変数 & 256 K ワード & $256 \mathrm{~K}$ ワード \\
\hline $\mathrm{I} / \mathrm{O}$ 変数 & $16 \mathrm{~K}$ ワード & $16 \mathrm{~K}$ ワード \\
\hline タグ & - & $\begin{array}{l}\text { 標準入出力（プロセスアラーム管理） } \\
\mathrm{HMI} / \mathrm{OIS}-\mathrm{DS} \text { インタフェース }\end{array}$ \\
\hline タスク 定周期タスク & $\begin{array}{l}\text { 超高速：0.5〜 } 500 \mathrm{~ms} \\
\text { 高速：0.5〜 } 500 \mathrm{~ms} \\
\mathrm{RIO}: 0.5 \sim 500 \mathrm{~ms} \\
\text { メイン：0.5〜1,000 ms }\end{array}$ & $\begin{array}{l}\text { 高速：10 500 ms } \\
\text { メイン：100〜 10,000 ms }\end{array}$ \\
\hline イベントタスク & $\begin{array}{l}\text { イベント }: 8 \text { 本 } \\
\mathrm{I} / \mathrm{O} \text { 割込み }: 16 \text { 本 }\end{array}$ & $\begin{array}{l}\text { イベント }: 8 \text { 本 } \\
\mathrm{I} / \mathrm{O} \text { 割込み }: 16 \text { 本 }\end{array}$ \\
\hline 演算性能 & \multicolumn{2}{|c|}{ ビット 接点: $20 \mathrm{~ns}$} \\
\hline プログラム言語 & \multicolumn{2}{|l|}{ IEC $61131-3$ 準拠 4 言語 } \\
\hline
\end{tabular}

環境・用排水等の設備があり, 当社では電気・計装・計算 機制御システムの様々なソリューションを提供している。 図 2 に，製紙工場において当社が提供している総合システ ム構成を示す。この総合システムは原単位管理, エネルギ 一運用計画，アラーム解析・適正化支援，統合帳票による 工場運営効率化システム, 運転デー夕診断, パトロール支 援による予防保全システム, 品質情報トラッキングによる 品質維持システムなどにより構成する。

情報の融合としては，部門を横断して情報を共有し，工 場の見える化を実現する製造情報統合データベース構築が 提案され，実績も上げている。本章では，工場全体の情報 融合の中でも，抄紙・調成設備に特化した情報共有につい て紹介する。

抄紙設備の電気制御システムは，主幹コントローラを中 心として, ワイヤ・プレス・ドライヤ・コーター・カレン ダ・リールの各セクションのドライブ装置に指令を行うこ とで速度制御を主体に行うものである。この速度制御は数 $\mathrm{ms}$ から数十 $\mathrm{ms}$ の高速処理周期内に実行しなければなら ない。これに対し, 抄紙・調成計装制御システムは, パル プ原料の配合・濃度調整, 塗料薬品の配合調整, 原料回収, ドライヤ温度管理などの制御を司る。システムは DCS (Distributed Control System) で構築され，コントローラの処 理速度は $1 \mathrm{~s}$ 以内である。このように, 同じ抄紙・調成設 備ではあるが，制御対象は異なり，処理速度も大きく異な っている。当社では, 電気制御コントローラと計装制御コ ントローラ共に, 東芝が 2007 年 10 月にリリースしたユニ ファイドコントローラ nv シリーズを採用し，ハードウェ アプラットフォームを統一している。処理周期の差異及び 計装特有の TAG データ取扱いなどにより, 電気制御用と 計装制御用の 2 種類のコントローラをリリースしている。 図 3 にユニファイドコントローラ nv シリーズの概観を示

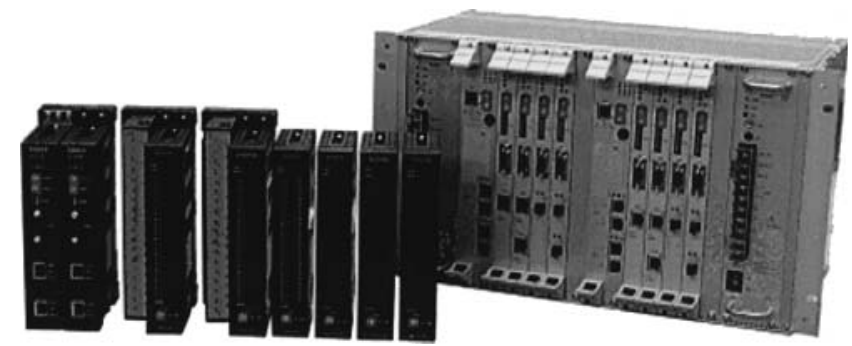

図 3 ユニファイドコントローラ nv シリーズ外観

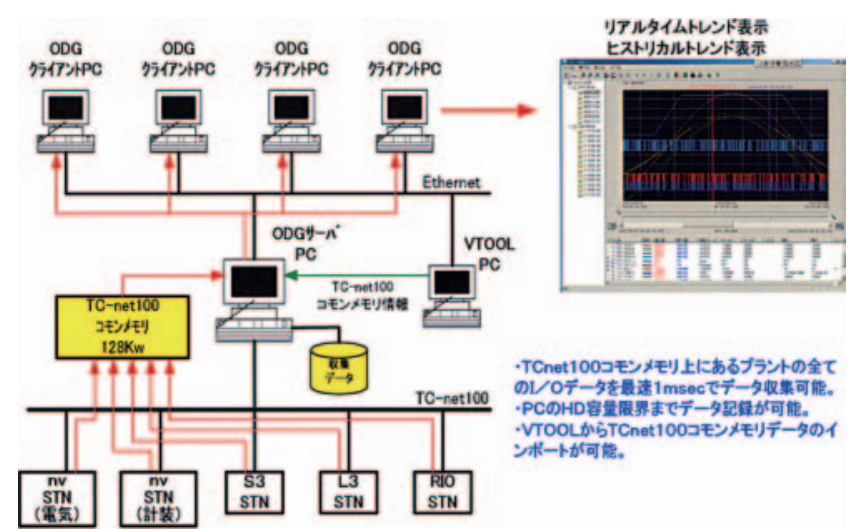

図 4 ODG 機能概要とシステム構成

す。

また，表 1 にユニファイドコントローラ nv シリーズの 電気制御用コントローラと計装制御用コントローラの仕様 を記載する。

このコントローラは新開発のプロセッサを搭載して演算 性能の高速化を図ると共に, マルチタスク対応スケジュー リング性能の向上により, 割込み応答性能を要求するアプ 
表 2 TC-net 100 伝送仕様

\begin{tabular}{|c|c|c|}
\hline \multicolumn{2}{|c|}{ 項目 } & 内容 \\
\hline \multicolumn{2}{|c|}{ データ伝送速度 } & $100 \mathrm{Mbps}$ \\
\hline \multicolumn{2}{|c|}{ 媒体アクセス方式 } & DOMA（Deterministic Ordered Multiple Access） \\
\hline \multicolumn{2}{|l|}{ 伝送路 } & スター型（伝送路二重化可能） \\
\hline \multicolumn{2}{|l|}{ 伝送距離 } & $\begin{array}{l}\text { 光ファイバ : } 2 \mathrm{~km} \\
\text { ツイストペアケーブル : } 100 \mathrm{~m}\end{array}$ \\
\hline \multicolumn{2}{|l|}{ ハブ段数 } & カスケード 2 段 \\
\hline \multicolumn{2}{|l|}{ 接続台数 } & 最大 254 ノード/システム \\
\hline \multicolumn{2}{|c|}{ 伝送モード } & $\begin{array}{l}\text { スキャン伝送 } \\
\text { 高速周期 : } 1 \mathrm{~ms} \sim 160 \mathrm{~ms} \\
\text { 中速周期：10 ms〜1,000 ms } \\
\text { 低速周期：100 ms〜10,000 ms } \\
\text { メッセージ伝送ＴCP/IP 系メッセージ送受信 }\end{array}$ \\
\hline \multicolumn{2}{|c|}{ スキャン伝送容量 } & $\begin{array}{l}128 \mathrm{~kW} / \text { システム（16 bits/Word） } \\
2,048 \text { ブロック/システム（64 Words/ブロック） } \\
\text { 送信容量 } 576 \text { ブロック/ノード（36 kW/ノード })\end{array}$ \\
\hline \multirow[t]{2}{*}{ ケーブル } & 電気 & カテゴリ 5 ツイストペアケーブル \\
\hline & 光 & 石英 GI ケーブル（62.5/125, 長波長）または（50/125, 長波長） \\
\hline \multirow[t]{2}{*}{ コネクタ } & 電気 & RJ-45 モジュラジャック \\
\hline & 光 & MT-RJ 形光コネクタ \\
\hline \multicolumn{2}{|l|}{ 接地方法 } & $\mathrm{D}$ 種専用接地（1 点接地） \\
\hline
\end{tabular}

表 3 ODG 基本仕様

\begin{tabular}{|c|c|}
\hline 項目 & 内容 \\
\hline サンプリング周期 & 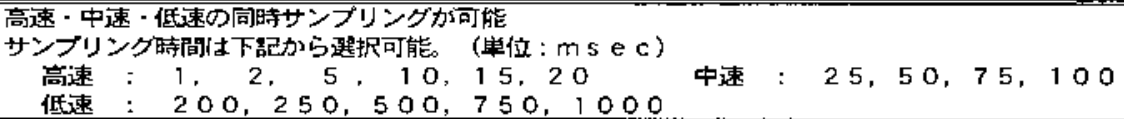 \\
\hline クライアント・サーパ搆成 & $\begin{array}{l}\text { 1台のサーバに最大10台のクライアントを接続可能 } \\
\text { サーバての操作とつライアントての操作は同一 }\end{array}$ \\
\hline 驱集データ保存童 & $\begin{array}{l}\text { 高速・中速・低速ごとに収集時间を設定可能 } \\
\text { 双集時間の設定によりHD使用量を表示 }\end{array}$ \\
\hline サンプリンダ点数 & PC能力限是专で双集可能 \\
\hline ヒストリカルトレンド表示挠能 & 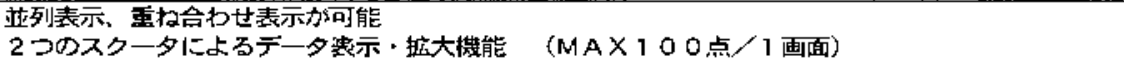 \\
\hline リアルタイムトレンド表示搭能 & 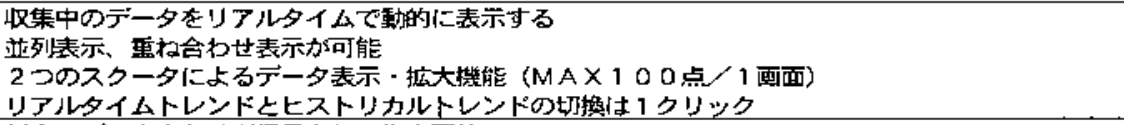 \\
\hline トリガ譏能 & 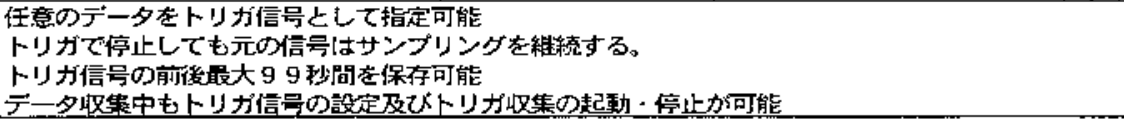 \\
\hline スナップショッ上捙能 & リアルタイムトレンド表示中 アイコンをクリックするたけでクラフ表示を保存可能 \\
\hline & 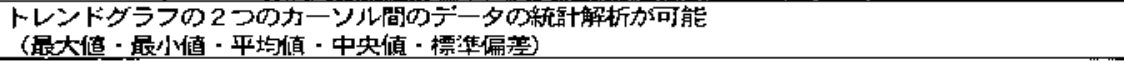 \\
\hline
\end{tabular}

リケーションでも高速処理を可能とするなどの特長を有す る。

紙切れなどの問題を総合的に解析したり, 品質改善を行 ったりするためには, 電気・計装両システムのデータが同 期されたデータベースが必要である。また，銘柄やロール
による紐付けが容易となる情報共有も必要である。当社で はコントローラ通信バスにリアルタイムイーサネットをべ ースとした TC-net 100 を採用し，リアルタイム性を確保 した高速データ収集を実現している。TC-net 100 の仕様 を表 2 に示す。この TC-net 100 は工業用リアルタイムイ 


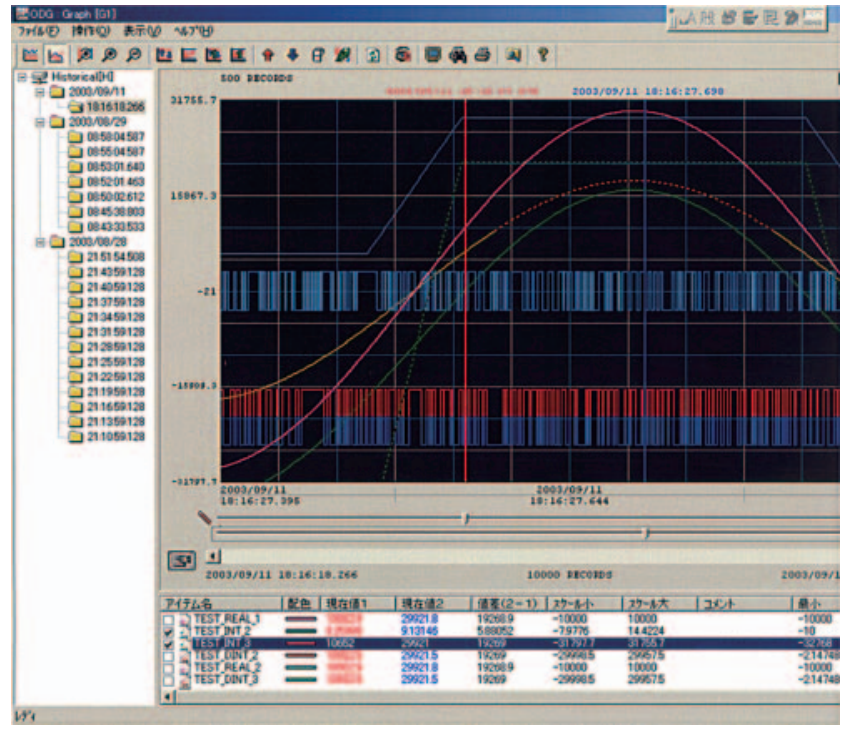

図 5 ODGトレンド画面表示例

ーサネットの国際標準である IEC 61784-2 を取得済である。 TC-net 100 で電気制御の高速処理周期に見合ったデー夕 収集を実現し, さらに計装制御コントローラを接続するこ とで, 電気・計装のデータ同期性を実現することも可能と なる。TC-net 100 は伝送コモンメモリ方式を採用してお り，128 ワードのデータを $1 \mathrm{~ms}$ の分解能で高速収集する ことも実現した。

この高速データ収集ネットワークによって，1 ms の分 解能でデー夕収集・解析ができる ODG (Online Data Gathering system）を実現した。図 4 に ODGの機能概要とシ ステム構成を示す。また, 表 3 は ODGの基本仕様をまと めたものである。
この装置にデータを取込み，ヒストリカル・リアルタイ ムトレンド機能，トリガ条件データ収集，スナップショッ 卜機能など, ODG の持つ様々な GUI 機能が問題解析や品 質改善を進める有効な手段となる。図 5 に ODG トレンド 画面例を示す。

実際の問題解析事例として紙切れ時の原因解析が挙げら れる。これまで紙切れの要因としてはドロー変動などの電 気的要因を主として解析していたが，これに不純物混入な ど原料要因や加圧不良，ドライヤ温度制御不良などの機械 的要因を計装制御システムからデー夕収集して ODG 上で 同期させることにより, 総合的に要因解析を行うことがで きる。当社が抄紙電気制御システムと抄紙・調成 DCS シ ステムを納入している設備において，ODGを適用した電 気・計装融合システム構成を図 6 に示す。これは, TC-net 100 インターフェイスカードを構成に加えて, 電気・計装 制御システムのデータを ODG にて統合するものである。

\section{4. 電気制御システム用監視装置と DCS オペレータ} ステーション・リアルタイムデータベースの融合

電気・計装制御システムのデータを ODG で統合するこ とで，従来は実現が困難であった $\mathrm{ms}$ オーダーのデータ収 集機能が実現可能であることを前章で述べた。ODGで収 集する高速周期データは主に問題解析用として位置付けら れる。

一方, 計装制御システムの重要な役割の一つとして, 実 操業データの収集・保存が挙げられる。当社ではその実現 手段として, リアルタイムデータベースである PLANET MEISTER のパッケージ群を用意し, 帳票機能, ヒストリ カルトレンド収集機能，イベントメッセージ収集機能及び 解析ツール等を必要に応じてシステムに取り入れている。

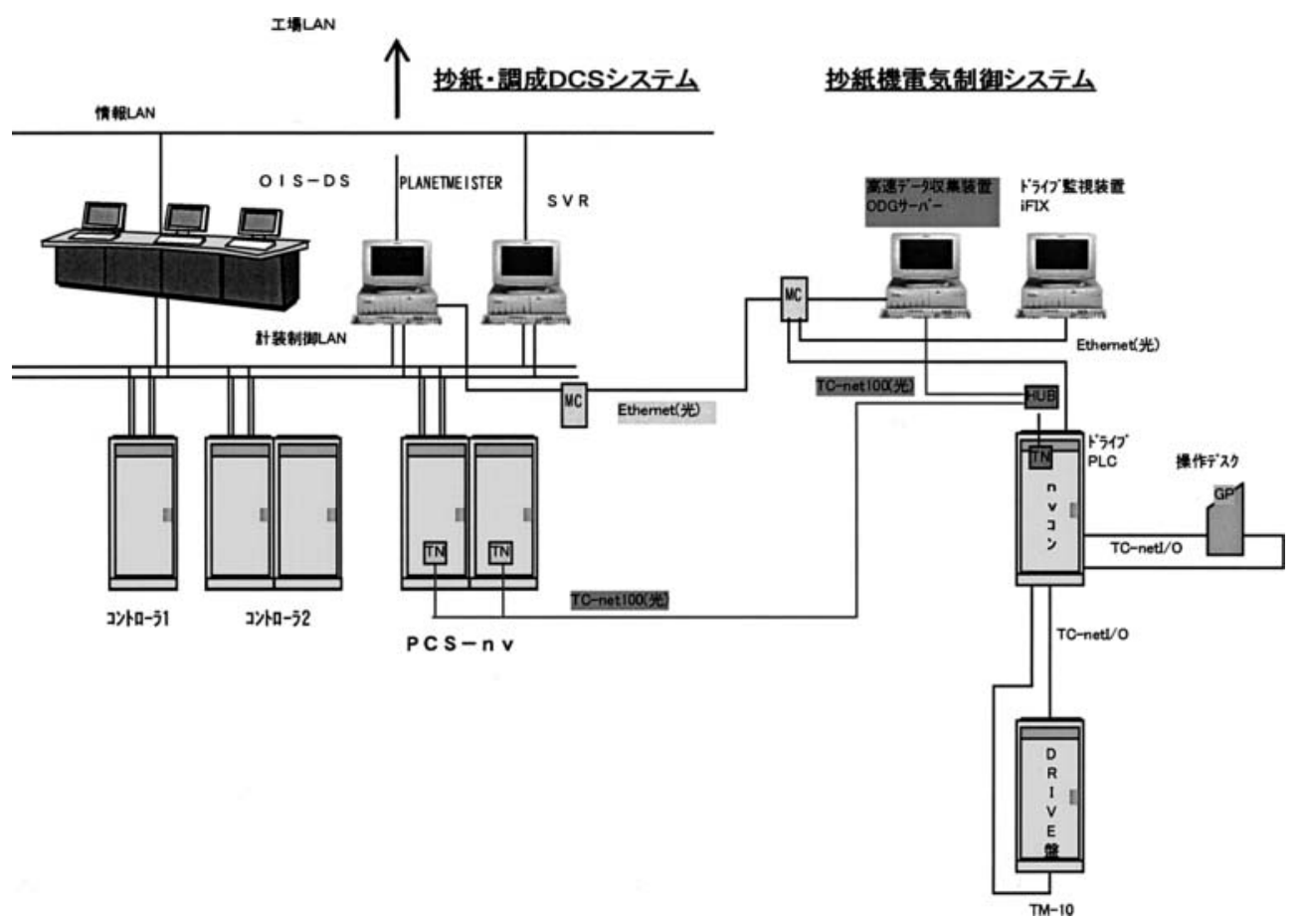

図 6 ODG 応用 電気・計装融合システム構成 


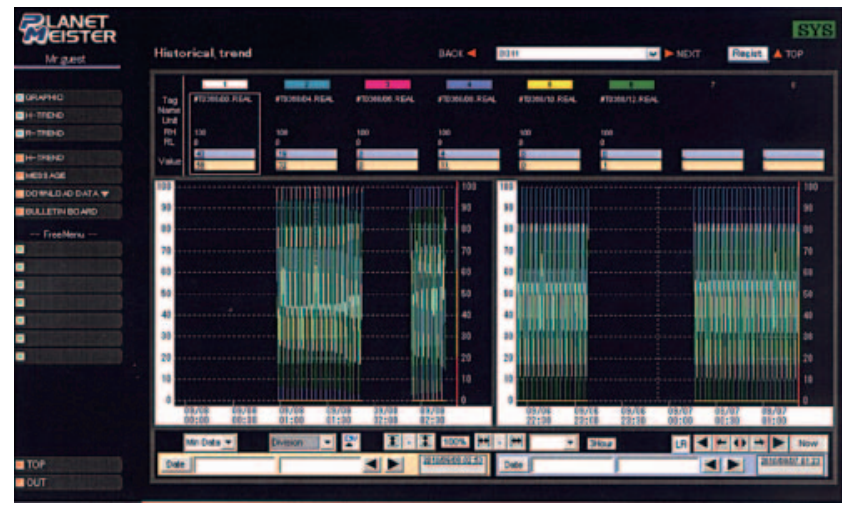

図 7 PLANETMEISTER ヒストリカルトレンド画面例

そこで, ODG の GUI と PLANETMEISTER の GUI を 1 台の PC で統合し, 電気・計装の操業データを一括監 視・管理することを可能とした。

ODG の GUI 機能の動作はもちろんのこと, PLANETMEISTER のヒストリカルトレンドに次の新機能も追加し た。

(1) 基準となる時間軸を固定し, 過去のデー夕を同一エ リアに表示させる重ね合わせ機能

(2) 異なる時間軸のデータを同一画面に表示する機能 （図７にサンプルを示す）

この重ね合わせトレンドや異なる過去データを 1 画面表 示する機能により, ベストな操業状態と問題発生時の操業 状態の乘離を把握し, 操業ガイドラインとしての活用を図 る事ができる。また, PLANETMEISTER は Web 機能も 装備しており, ネットワークを介したクライアントで Internet Explorerによって帳票, ヒストリカルトレンド, イベントメッセージのデータを表示させる機能も提供する。
電気・計装制御システムの融合をさらに進め, HMI の 統一化を計画中である。中央操作室と電気室で分離してい ることの多い計装用 HMI と抄紙機電気用 HMI を統一化 し, 中央操作室に集中させる構想である。保守・メンテナ ンスの対象となる機器を減らし，ランニングコストの軽減 にも寄与できると考えている。

\section{5. 電気・計装エンジニアリングの融合}

電気・計装制御システムの融合を進めるに当たり，エン ジニアリングの統一化も重要となってくる。電気・計装共 にユニファイドコントローラnv シリーズを採用し，ハー ドウェアプラットフォームを統一している。処理周期の差 異及び計装専用の TAG データ取扱いなどにより, 電気制 御用と計装制御用の 2 種類のコントローラをリリースして いるが，エンジニアリングッール “nV-tool 4” は同一で ある。図 8 にプログラミング作成画面の例を示す。同一プ ログラムタスク内に, 論理型, 順序型シーケンス制御とル ープ制御ロジックを混在表記することが可能である。図 9 はオンラインモニ夕画面の例である。オンラインモニタ画 面では, 論理制御信号は $\mathrm{ON}$ で赤・ OFF で黒, 変数デー 夕は下部に数值表示, 順序型シーケンスは実行中ステップ を赤色表示する。

nV-tool 4 は, 国際標準言語 IEC 61131-3 命令をサポー トし, LD (Ladder)/FBD (Function Block Diagram)/SFC (Sequence Function Chart)/ST (Structured Text) に対応 している。その特徴は下記の通りである。

(1) 技術の共有化及び資産の継承

(2) ハードベンダ依存からの脱却

(3) 制御ソフトのマルチベンダー化

(4) ブロック構造の多様化

従来, 当社の計装プログラミングは, 連続ループ制御,

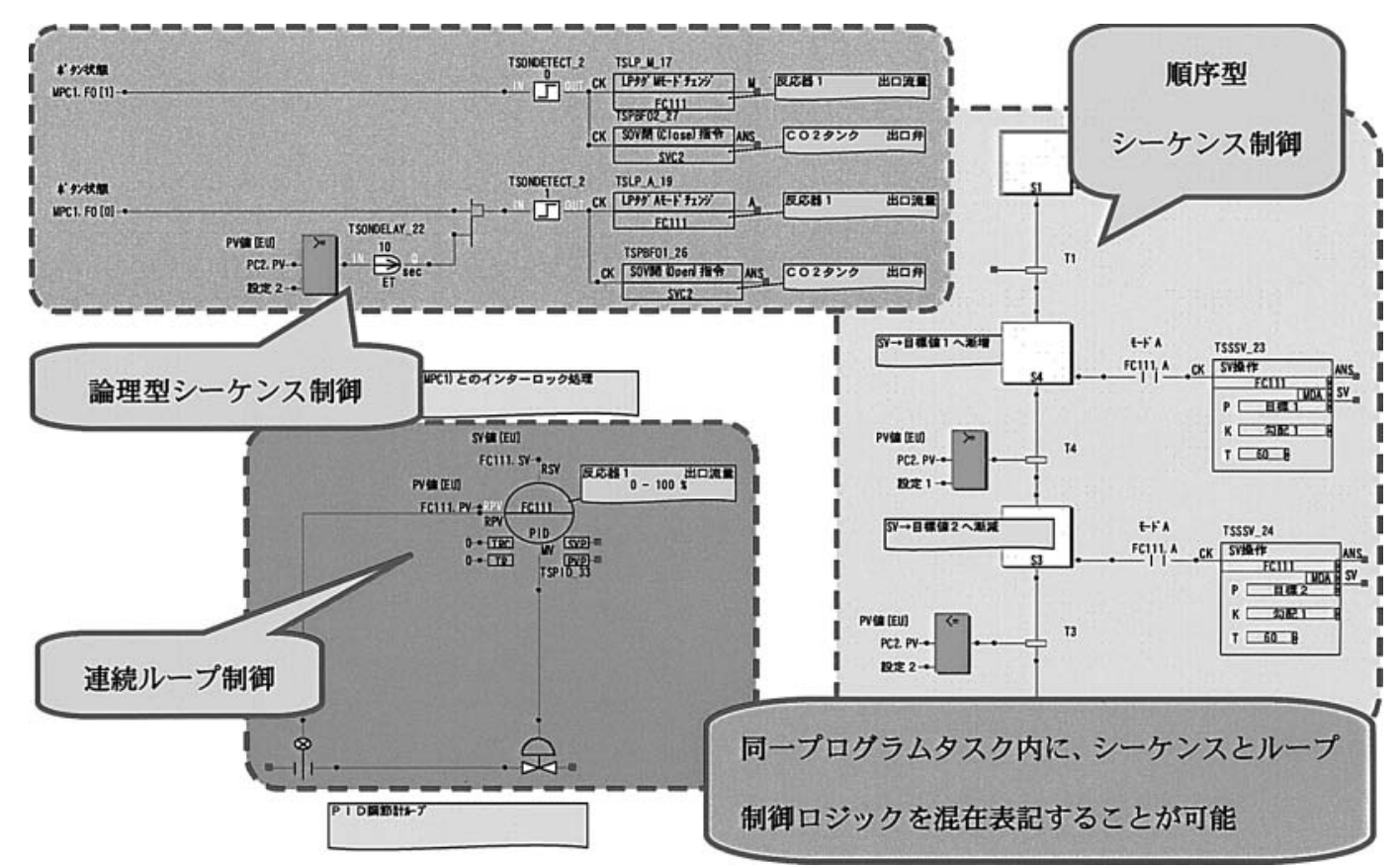

図 $8 \mathrm{nV}$-tool 4 画面例 


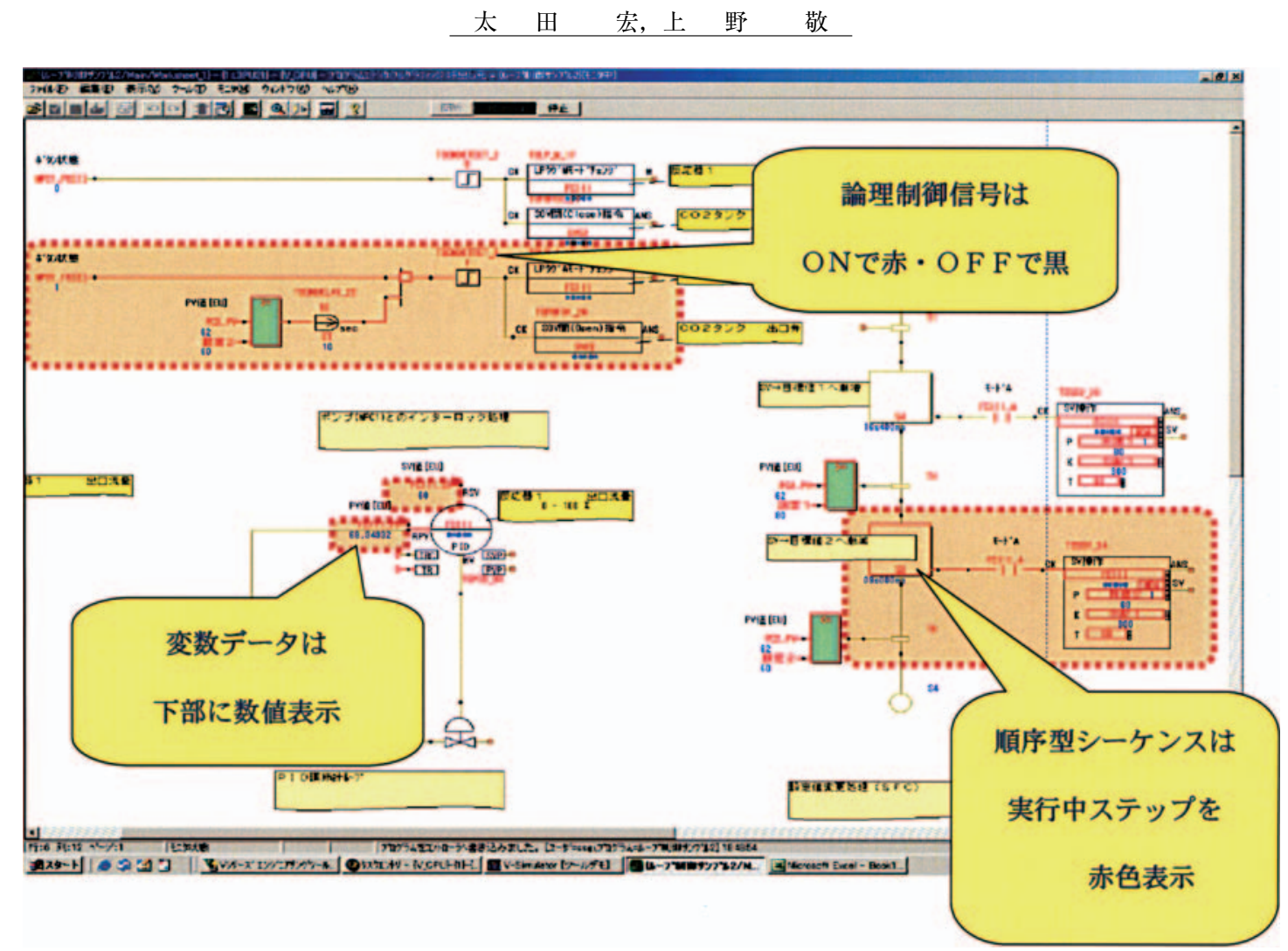

図 $9 \mathrm{nV}$-tool 4 でのオンラインモニタ例

論理型シーケンスロジック (ラダー), 順序型シーケンス ロジック（フローチャート）を個別のプログラム単位で構 築していたが，図 8 に示すように混在表記を可能にした。 これにより, 従来のプログラム単位間でデータ引き渡しを 行う中間パラメータの削減，ロジックの整合性チェック時 間の短縮など，エンジニアリングの容易性が実現される。 電気制御は主にラダー（LD）で構築されており，信号 名称，ロジック補助のコメント等を多用して処理順序，夕 イミングの整合性を取ることが重要となる。そこで, 信号 レベルでの管理の容易性を目的として電気制御に TAGを 導入し, 電気・計装一体となるプログラミング体系を計画 中である。これにより, 電気・計装の技術者の交流が一層 促進されるものと考える。

\section{6. むすび}

当社では, 電気・計装制御システム互いの特長を共有す ることにより, 特徴ある独自の融合システムを構築するこ
とが可能である。本稿では一部の紹介に留まったが，新設， 増設, 更新等あらゆる場面にマッチするシステムソリュー ションを提案することができる。加えて, 統一されたハー ドウェアプラットフォームであるユニファイドコントロー ラ nv シリーズは，従来機種と比較して性能が向上してお り，電気・計装両分野での適用範囲拡大が今後も期待され る。

[注記]

・TC-net は(侏)東芝の登録商標

・PLANETMEISTER は東芝三菱電機産業システム(株)の 登録商標

・イーサネットは富士ゼロックス(株)の登録商標

・ Internet Explorer は Microsoft 社の登録商標

\section{Reference}

日下部宏之, 登古誠, 梅田裕二：「産業用コントローラの 新展開」東芝レビュー 62 (10)，2007 年 10 月 